\title{
Education (selfcare) in Tuberculosis Patients With Experimental Quasi Design
}

\author{
$1^{\text {st }}$ Tri Wahyuni \\ Nursing Study Program \\ STIK Muhammadiyah Pontianak \\ Pontianak, Indonesia \\ tri@stikmuhptk.ac.id
}

\author{
$2^{\text {nd }}$ Almumtahanah \\ Nursing Study Program \\ STIK Muhammadiyah Pontianak \\ Pontianak, Indonesia
}

\author{
$3^{\text {rd }}$ Niken Tari Dewi \\ Nursing Study Program \\ STIK Muhammadiyah Pontianak \\ Pontianak, Indonesia
}

\begin{abstract}
Tuberculosis is an infectious disease that attacks the lungs typically characterized by the formation of granulomas and causes tissue necrosis, an infectious disease directly caused by the TB germ (mycobacterium tuberculosis). The problem that often arises in tuberculosis sufferers is about self-care related to nutrition, treatment, increased transmission, and psychosocial family support activities. The purpose of this study was to determine the effect of self-education care on anxiety reduction in tuberculosis patients. The research design used is quantitative with the design Quasi Experimental pre-test post-test without a control group. The sample in this study was 30 samples given intervention booklet. Based on bivariate analysis of activity (behavior) and knowledge with the Test shows that in education with this assistance self-care affects the decrease in anxiety in patients with tuberculosis activity variable (behavior) with $p$-value 0.029 and knowledge with $p$-value 0.050 which means $p$ value $<\boldsymbol{\alpha} 0.050$ this research shows the differences in educational scores before and after the intervention. with assistance telenursing. Self-education care can change the activity (behavior) and knowledge in TB patients.
\end{abstract}

Keywords-educational, seflcare, tuberculosis

\section{INTRODUCTION}

Tuberculosis is an infectious disease that attacks the lungs typically characterized by granuloma formation and causes tissue necrosis [22]. It has been known more than a century ago, namely after the discovery of TB germs by Robert Koch 1882, but until now TBC remains a global health problem and global challenge in Indonesia [4]. A direct infectious disease caused by TB germs (mycobacterium tuberculosis) (Black \& Hawks, 2014).

Based on data from the World Health Organization (WHO) in 2013 there were 9 million people in the world who were infected with TB germs (WHO, 2014). In 2014 there were 9.6 million world population infected with TB germs [23] and the highest number of pulmonary TB cases were in Africa (37\%), Southeast Asia (28\%) and the Eastern Mediterranean region (17\%) [23].

In Indonesia, the prevalence of pulmonary tuberculosis is grouped into three regions, namely Sumatra (33\%), Java and Bali (23\%), and Eastern Indonesia (44\%) (WHO, 2008). Pulmonary tuberculosis is the third leading cause of death after cardiovascular and respiratory diseases in all age groups and is number one for infectious diseases. The death toll from pulmonary tuberculosis in Indonesia is estimated at 61,000 deaths each year [21]. The success of treatment in Indonesia is still below the WHO standard of $85 \%$ and Indonesia is still $81.3 \%$ [5].

In West Kalimantan, the prevalence of TB in 2013 was the highest number of positive smear in the 45-54 year age group, which was $20.54 \%$ of 973 patients. In 2014 , the highest number of tuberculosis in the $45-54$ year age group was $20.29 \%$ of 833 sufferers and in 2015 . Efforts to handle the government's DOT'S program have been carried out but treatment problems are hampered because in TB cases the treatment is quite long in the intensive phase of 2 months and a 4-month advanced phase. A minimum conversion target of $80 \%$ at the intensive stage (PPTI, 2017). Related research was conducted by [3] about differences in the effect of antituberculosis drugs (OAT) fixed-dose combination (KDT) compared to the release of acid-resistant bacillus sputum conversion at the end of the intensive phase. In tuberculosis patients, there were no significant differences in KDT OAT compared to the release of smear sputum conversion (acid-resistant bacteria) at the end of the intensive phase in adult TB patients $(\mathrm{p}=0.644)$. Treatment is effective if supported by family support in TB patients.

Efforts to overcome the nursing problems that occur in TB patients are carried out by increasing support for patients as the main supporter of family and health workers Interventions conducted by patients as agents for themselves are known as (self-care). Self-care was developed by Orem, 1971 in [2] states that nursing care is carried out with the belief that everyone can take care of themselves so that it helps Individuals meet the needs of life, maintain health and well-being, known as self-care. Self-care in TB patients can be done to overcome nursing problems that arise by preventing the spread of infection, improving treatment, increasing nutritional needs and addressing psychosocial problems so that recovery can be achieved.

Booklets are the best solution so that clients keep in mind the offers that have been made. This is defined as the use of information technology in the field of nursing to provide health services in the form of information or monitoring, where there is a physical distance between nurses and clients [1] [10]. The Pontianak community in West Kalimantan mostly carries out treatment in hospitals or health centers or health installations. Usually given health education, this can be the best strategy in conducting education counseling self-care using booklets. 
This potential can be used to improve nursing services by involving patients in self-care. Based on the above explanation, researchers feel the need to research the Effects ofEducation Self Care with the QuasiExperimental Method at UPT Pontianak Lung Health Services.

\section{RESEARCH METHODS}

This research is a study using a quasi-experimental design with a non-randomized pretest without control group design [19]. In this study, tests were conducted before the respondent was given treatment. The test is done by measuring self-care conducted on TB patients using interviews and questionnaire measurement tools [12]. The design of this study uses a quantitative approach, the researcher wants to know respondents before education self-care and after education self-care.

\section{RESEARCH RESULTS}

A. Univariate analysis TABLE 1. DISTRIBUTION OF RESPONDENTS BY SEX

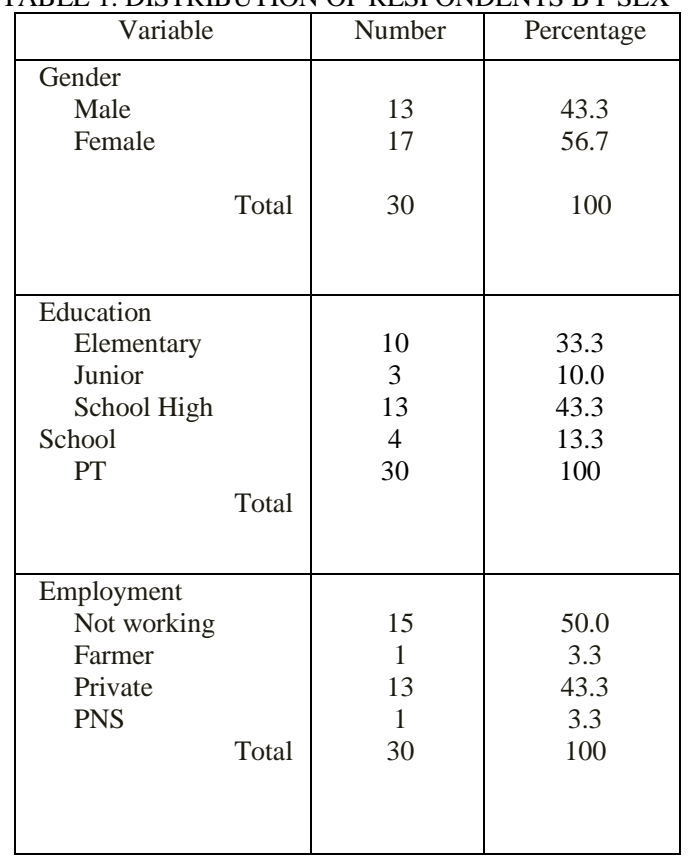

Based on the table 1, shows that the distribution of respondents by sex shows that most respondents were female respondents totaling 17 respondents (56.7\%). Characteristics of respondents by education level indicate that the average respondent has a high school education background of 13 respondents $(43.3 \%)$. While the distribution of respondents based on work most respondents do not work for 15 respondents $(50.0 \%)$.
TABLE 2. DISTRIBUTION OF DATA KNOWLEDGE AND BEHAVIOR BEFORE AND AFTER THE EDUCATIONAL

\begin{tabular}{|l|c|l|c|}
\hline Variable & $\begin{array}{c}\text { Measure } \\
\text { ments }\end{array}$ & Variable & $\begin{array}{c}\text { Measureme } \\
\text { nt }\end{array}$ \\
\hline Knowled & Prior & & Prior \\
ge & 13.77 & Mean & 13.77 \\
Mean & $14: 00$ & Median & $14: 00$ \\
Median & 0626 & Standard & 0626 \\
Standard & $12-15$ & Deviation & $12-15$ \\
Deviatio & & Min-Max & \\
n & & & \\
Min-Max & & & \\
\hline
\end{tabular}

Based on table 2, shows that the knowledge and behavior variables with data characteristics namely the mean value after education is greater than the mean value before educational provision. The mean value also shows the difference in the two variables with the measurement after education is higher than the value before education.

B. Knowledge and behavior before and after education TABLE 3. KNOWLEDGE AND BEHAVIOR BEFORE AND AFTER

\begin{tabular}{|c|c|c|c|}
\hline Variable & $\begin{array}{c}\text { Mean } \\
\text { (Min - Max) }\end{array}$ & $\begin{array}{c}\text { Std } \\
\text { Deviation }\end{array}$ & P-value \\
\hline $\begin{array}{r}\text { Knowledge } \\
\\
\end{array}$ & $13.77(12-15)$ & 0.626 & 0,000 \\
\hline Post & $27.60(22-28)$ & 1,329 & \\
\hline $\begin{array}{r}\text { Behavior } \\
\text { Pre }\end{array}$ & $13.43(12-14)$ & 0.728 & 0,000 \\
\hline Pre & $50.33(36-54)$ & 6.784 & \\
\hline
\end{tabular}

Obtained the significant value of the two variables both knowledge and behavior is $0.000(\mathrm{p}<0.05)$, thus it can be concluded that there is an influence of education on the level of knowledge and behavior.

\section{DISCUSSION}

\section{A. Education}

The results of this study indicate that the characteristics of respondents based on education, Characteristics of respondents based on their level of education indicate that the average respondent has a high school education background of 13 respondents (43.3\%).

The results of this study are in line with Rusmani's research (2002) that there is no relationship between education and compliance with treatment for patients with pulmonary tuberculosis and research study by [6] that there is an educational relationship with disobedience in treatment in patients with pulmonary TB. This means that there is no relationship between education and medication adherence. According to [16], education is a motivating reason for someone to behave, but this study was not proven even though more than half of the responses were high school educated.

Researchers analyzing high levels of education will help get information so that it becomes the patient's knowledge and experience in self-care about the illnesses 
of the respondents in the problems or complaints they experience. The information obtained by respondents will make the client's experience to be able to self-care properly.

\section{B. Work}

The results of this study indicate that the characteristics of respondents based on work, most respondents do not work for 15 respondents $(50.0 \%)$, but the results of the study stated that of 32 respondents $50 \%$ of clients do not work this is caused by declining health factors causing patients to choose to stop working. But some are still actively working because of economic demands and position as head of the family. This is in line with research conducted by [17] with the title of the relationship between the characteristics of TB patients with sputum compliance during treatment. This research is an observational analytic study with design cross-sectional. Data were obtained from 38 respondents. Sampling using simple random sampling technique with client research results still working status $(\mathrm{p}=1.00)$ is not related to compliance in sputum examination during treatment.

\section{Gender}

The results of this study indicate that the characteristics of respondents based on gender are mostly female, amounting to 17 respondents $(56.7 \%)$. Gender is a variant of living things divided into male and female variants which are referred to as sex or sex.

Based on the results of Dotulang's research, 2015 with the title the relationship of risk factors for age, sex and occupancy density with the incidence of pulmonary TB disease in Wori Village, wori District, the results of 58 women and 39 men with a p-value of 0,000 . This is in line with syafullah research, 2018 with the title Factors Associated with Lung Tuberculosis Health Care Behavior with research results of 63 men $(71.59 \%)$ and 25 women (28.40\%).

\section{Activity (Behavior)}

The results of this study state that the activity (behavior) of TB patients after education is self-care obtained different results. Wilcoxon signed-rank test,visible knowledge of the respondent before treatment behaviors seen values obtained before treatment the mean values of respondents were 13:43, the lowest score was 12 and the highest is 14 . While the results of analysis on the behavior of respondents obtained after treatment the average value of behavior is 50.33, the lowest value is 36 and the highest is 54 showing the mean value before 13.43 (12-14) with SD 0.728 and $s$ after treatment the mean value is 50.33 (36-54) with SD 6.784 with a p-value of 0.000 indicating a difference before and after treatment.

Based on research [15] the relationship between individual characteristics, hygiene practices and environmental sanitation with the incidence of tuberculosis in North Semarang sub-district with 30 respondents the results of research on the habit of not closing the mouth when coughing $(56.7 \%)$ and the habit of sputum exposing in any place (86 7\%). From these studies, it can be concluded that the contact history of patients with pulmonary tuberculosis and the work environment is a risk factor for the incidence of pulmonary TB.

Research [20] with the title Factors of pulmonary tuberculosis patients with drug withdrawal. Stating that there is a meaningful relationship between attitude and healing this can be shown by the value of $\mathrm{OR}=6,200 \mathrm{p}=$ $0.012 ; 95 \% \mathrm{CI}=1,644-23,917$. This means that people who have bad attitudes or assumptions have a 6.2-time chance to experience no cure when compared to people who have good attitudes.

Based on the cross-tabulation conducted by [9] with research on factors related to the regularity of taking drugs for patients with pulmonary tuberculosis in the working area of the Modayag Puskesmas, Bolaang Mongondow Timur Regency, between attitude and regularity of taking drugs, with p-value $=0.005<0,05$ which shows there is a significant relationship between attitude and regularity of taking medication, with an OR value of 8,800 .

Researchers analyzed in the study of self-care behavioral(activities) in TB patients after education was done self-care there was a significant increase in the mean results. While comparing after treatment according to the analysis of researchers, which means there are significant differences between the results of the post-test. This means, there is an influence of self-care education on anxiety reduction in pulmonary TB patients.

\section{E. Knowledge about Treatment}

The results of this study state that knowledge about treatment in TB patients after self-care education is done to obtain significant differences in results. Wilcoxon signed-rank test,before treatment the mean value obtained 13.77 , the lowest score was 12 and the highest is 15 . While the results of the analysis of respondents' knowledge obtained after treatment the average value of knowledge are 27.60, the lowest score of 22 and the highest is 28 . Before treatment show the mean value of 13.77 with SD 0.626 while after treatment of education self-care showed a mean value of 27.60 with SD 1,329 with a p-value of 0,000 .

Related research was conducted by [3] about the differences in the effects of fixed-dose combination (KDT) anti-tuberculosis (OCT) drugs compared to release of acid-resistant sputum bacilli conversion at the end of the intensive phase. In tuberculosis patients, there was no significant difference between KDT OAT compared to the release of smear sputum ((acid-resistant bacteria) conversion at the end of the intensive phase in adult TB patients $(p=0.644)$. [18] research with the title factor related to the standard treatment of tuberculosis patients. Researchers explained that most patients who drop out of treatment are those who have little or no explanation of the disease. Lack of knowledge about the benefits of completing treatment $(25.23 .1 \%)$ with a value $(\mathrm{P} \leq 0.05)$. It can be concluded there is a significant relationship between the knowledge of the incident broke treatment in patients with the standard treatment of tuberculosis patients.

Researchers analyzed in the study self-care knowledge of treatment in tuberculosis patients after doing educating self-care is no increase in the results mean significant. 
While comparing the after treatment according to researcher analysis, which means there are pe Significant differences between post-test results. This means, there is an influence of education self-care on anxiety reduction in pulmonary TB patients.

\section{CONCLUSION}

- The sexes in males amounted to 17 people (56.7) and females 13 people (43.3), the level of education was more at the level of 13 high school education $(43.8 \%)$. While the status of work does not work 15 people $(50.0 \%)$, private work 13 people (43.4), farmers 1 person $(3.3 \%)$ and civil servants 1 person $(3.3 \%)$

- There are differences in self-care activities (behavior) in TB patients after education treatment obtained $\mathrm{p}$ value 0,020 .

- There is a difference in self-care in knowledge in tuberculosis patients after the educational treatment obtained a p-value of 0,000 .

\section{REFERENCES}

[1] Anton Tribowo, 2015. Karakteristik TB Paru Dewasa Di Balai Besar Kesehatan Paru Masyarakat Surakarta, 2015.

[2] Alligood, M.R. \& Tomey, A.N. (2014). Nursing Theorist and their workn Edition 2, ST. Louis: Mosby

[3] Caesar, Marini Daniar,(2014). Perbedaan Efek Obat Anti Tuberkulosis Kombinasi Dosisi Tetap Dibanding Lepasan Terhadap Sputup Basil Tahan Asam Saat Akhir Fase Intensif Pada Pasien Tuberkulosis Dewasa Di Balai Besar Kesehatan Paru Masyarakat Surakarta. Universitas Muhammadiyah Surakarta.

[4] Depkes RI. 2009. Pedoman penanggulangan tuberkulosis di Indonesia (PPTI). Jakarta: Depkes RI

[5] Depkes RI. 2015. Pedoman penanggulangan tuberkulosis di Indonesia (PPTI). Jakarta: Depkes RI.

[6] Erni Erawatyningsih dkk. Faktor-faktor Yang Mempengaruhi Ketidakpatuhan Berobat Pada Penderita Tuberkulosis Paru Factors Affecting Incompliance with Medication Among Lung Tuberculosis Patients. Program Studi Ilmu Keperawatan, FK UGM, Yogyakarta vol 5, 2009.

[7] Farid Setyo, dkk.2018 Gambaran Perilaku Pengobatan Pasien TB MDR Fase Intensif Di RS DR Moewardi Surakarta. Universitas Diponegoro.

[8] Hidayati, 2015. Pengetahuan dan Stigma Masyarakat terhadap TBC Setelah Diberikan Pendidikan Kesehatan Pencegahan dan Penularan.Fikes UNSOED.

[9] Ni Wayan Ariani dkk. Faktor-faktor Yang Berhubungan Dengan Kepatuhan Minum Obat Penderita Tuberkulosis Paru Di Wilayah Kerja Puskesmas Modayang, Kabupaten Bolaang Mongondow Timur. Vol 5, 2015.

[10] Nurhidayah, R. E. 2010. Pendidikan Keperawatan. Medan: USU Press

[11] Nursalam, 2008. Konsep dan penerapan metodologi penelitian keperawatan. Jakarta: Salemba Medika

[12] Notoatmodjo, Soekidjo. 2010. Promosi Kesehatan Teori dan Aplikasi. Jakarta: Rineka Cipta.

[13] Nurhidayati Istiana, 2010.Peran Keluarga Pada Kepatuhan Minum Obat Penderita TB di Kawedanan Pedan Kelaten. Stikes Muhammadiyah Klaten

[14] Pedoman dignostik \& Penatalaksanaan Penyakit Paru di Indonesia (Konsenseus Paru ), 2017. Jakarta

[15] Pertiwi, 2012. Hubungan Antara Karakteristik Individu, Praktik Hygiene dan Sanitasi Lingkungan Dengan Kejadian TBC di Kecamatan Semarang Utara. Jawa Tengah

[16] Refica Dewita dkk. Gambaran Pengetahuan Dan Sikap Pasien TB Paru Terhadap Upaya Pengendalian TB Di Puskesmas Sidomulyo Kota Pekanbaru, 2017
[17] Ruditya, DN. 2015.Hubungan antara karakteristik penderita TB dengan kepatuhan memerikasakan dahak selama pengobatan. Fakukultas kesehatan Universitas Airlangga, Surabaya, Jawa Timur.

[18] Slama et al, 2013. Faktor yang terkait dengan standar pengobatan pasien tuberculosis.

[19] Sugiyono. 2009. Statistika Untuk Penelitian. Bandung: Alfabeta.

[20] Umar Firdaus dkk. Faktor-faktor penedrita tuberkulosis paru putus obat, vol 16, no 4 desember. 2006.

[21] World Health Organization, 2011.Global tuberculosis control: WHO report (WHO/HTM/TB /2013), Geneva.

[22] World Health Organization, 2013. Global tuberculosis control: WHO report (WHO/HTM/TB /2013), Geneva.

[23] World Health Organization, 2015. Global tuberculosis control: WHO report (WHO/HTM/TB /2013), Geneva. 